\title{
REGULATING PRIVATE SECURITY COMPANIES (PSCs) AND PRIVATE MILITARY COMPANIES (PMCs) UNDER THE LAW OF TIMOR-LESTE*
}

\author{
Salvador Soares** and David Price ${ }^{* * *}$ \\ School of Law Charles Darwin University, Darwin \\ Ellengowan Dr, Casuarina, Northern Territory 0810, Australia
}

\begin{abstract}
Use of Private Security Companies (PSCs) and Private Military Companies (PMCs) in conflict and post-conflict countries has been the subject of ongoing critical discussion among scholars and media for many years. This paper assesses the legal status and responsibilities of PSCs and PMCs, and their operation in Timor-Leste where they are not properly regulated. It examines key legal issues, such as their definition and roles, scope and limits of operations, approved and prohibited activities, accountability, and monitoring. The paper also examines the impact of PSCs and PMCs on Timor-Leste law and society and offers astatutory framework for their management and regulation.
\end{abstract}

Keywords: PSCs, PMCs, law of Timor-Leste.

\section{Intisari}

Implementasi Private Security Companies (PSCs) dan Private Military Companies (PMCs) dalam negara yang sedang berkonflik dan pasca berkonflik telah menjadi subjek pembahasan penting diantara akademisi dan media massa selama bertahun-tahun. Penulisan ini akan menilai status hukum dan kewajiban PSCs dan PMCs, dan pelaksanaan kerja kedua lembaga tersebut di Timor-Leste dimana belum ada pengaturan yang mumpuni. Penulisan ini menganalisa isu-isu krusial mengenai beberapa pengaturan, seperti definisi dan peran, batasan dan ruang lingkup kerja, aktivitas yang diperbolehkan dan yang dilarang, akuntabilitas, serta pengawasan. Penulisan ini juga menganalisa implikasi dari PSCs dan PMCs di tatanan hukum dan masyarakat Timor-Leste, serta menawarkan sebuah kerangka undang-undang untuk manajerial dan pengaturan kedua lembaga tersebut.

Kata Kunci: PSCs, PMCs, law of Timor-Leste.

\section{Pokok Muatan}

A. Background 473

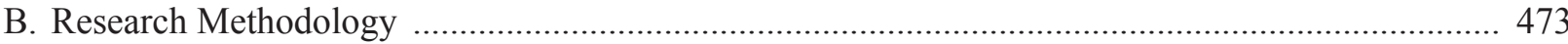

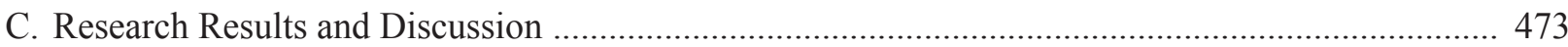

1. Definition, Legal Status, and Accountability of PSCs and PMCs ............................................ 473

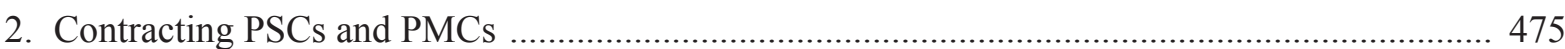

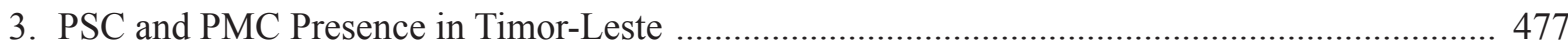

4. PSC and PMC Regulation in Timor-Leste Legal System ........................................................ 479

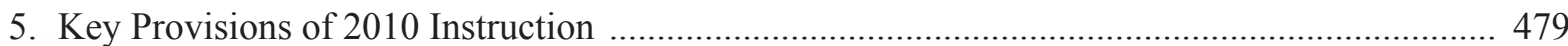

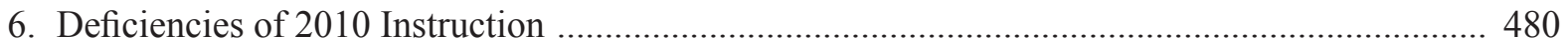

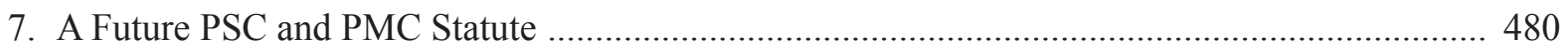

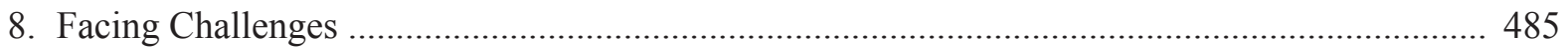

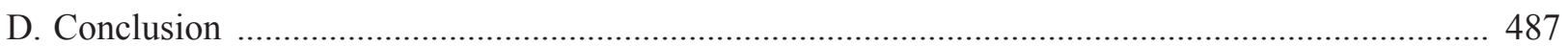

Research Result by the School of Law, Charles Darwin University in 2014.

Correspondence address: salvador_soares71@yahoo.com

** Correspondence address: david.price@cdu.edu.au 


\section{A. Background}

Private Security Companies (PSCs) and Private Military Companies (PMCs) have existed and operated for many generations in one guise or another, but they have gained emerging and prominent profiles with the demise of the Soviet Union and the end of the Cold War. After the Cold War, many countries that had once allied themselves to the Soviet Union or the United States started to experience an increasing number of armed conflicts from both internal and external sources that the superpowers previously would have kept under control and prevented from spreading. ${ }^{1}$ Furthermore, domestic conditions deteriorated with the absence of well-established authority in these countries and inadequate armed forces and law security agencies with capability to maintain order and internal security. ${ }^{2}$ These state organs were often incapable of maintaining adequate capacity and capability levels without the support and assistances similar to that received during the Cold War period from the superpower countries. ${ }^{3}$

These post-Cold War conditions provided a suitable environment for the development of PSCs and PMCs, since the companies were eager to fill the security void left by the superpowers. ${ }^{4}$ Countries that once depended on the superpowers now turned to PSCs and PMCs in order to support and maintain their internal security, thereby creating demand for the security market. ${ }^{5}$

This paper assesses the legal status and responsibilities of PSCs and PMCs in Timor-Leste, in the absence of proper regulation. It examines key legal issues, such as definition, the scope and limits of operations, approved and prohibited activities, accountability, and the regulatory framework for PSC and PMC monitoring and management. It also examines their impact on Timor-Leste society and offers a statute for their management and regulation.

\section{B. Research Methods}

The methodology of this research is normative legal research, based on core principles, norms, and regulations of legal frameworks. It relies on primary and secondary data gathered from the Timor-Leste government, PSC offices in Timor-Leste, and United Nations documents relating to PSCs and PMCs. It also utilises national legislations relating to the use of PSCs and PMCs from other countries, such as the United States, the United Kingdom, South Africa, and Indonesia.

\section{Research Results and Discussion \\ 1. Definition, Legal Status, and Accountability of PSCs and PMCs}

The International Code of Conduct for Private Security Services Providers, a joint initiative sponsored by the International Committee of the Red Cross and the Swiss Government, defines PSCs as companies whose business activities include the provision of security services either on its own behalf or on behalf of another, irrespective of how such a company describes itself. ${ }^{6}$ In respect of PMCs, the Geneva Centre for the Democratic Control of Armed Forcesdescribes such companies as 'business that offers specialised services related to war and conflict, including combat operations, strategic planning, intelligence collection, operational and logistical support, training, procurement and maintenance. ${ }^{7}$

However, in a number of areas of operation, such as Iraq and Afghanistan, it has been very difficult to distinguish between PSCs and PMCs in practical terms, since both organisations frequently

\footnotetext{
Peter Singer, 2003, Corporate Warriors: The Rise of the Privatized Military Industry, Cornell University Press, New York, p. 50. Ibid., pp. 50-51. 
perform the same or similar types of tasks. This difficulty is exacerbated by the lack of statutory instruments defining PSCs and PMCs and their legal status. ${ }^{8}$ Additionally, some PMCs describe themselves as PSCs because they perform security services usually conducted by PSCs, and to avoid negative public attention and monitoring by external regulations that could have negative impact on their business development. ${ }^{9}$

Nevertheless, they are two different organisations, with PMCs having a military nature and most PSCs being more civilian and ancillary to law enforcement in nature. To distinguish between the types of companies, anapproach that reviews their activities in the areas of operation is required, taking account of the condition of the states where they conduct their operations and whether or not they are conducted in peaceful or in armed conflict situations.

PSC and PMC legal status has become the subject of much discussion among scholars. Parker argues that the nature of the services and tasks of PSCs and PMCs determine the classification of their legal status, even when there is no agreed definition for non-state security providers whether they are PSCs, PMCs, or just mercenary forces. ${ }^{10}$ Besides depending on the nature of their activities, Gillard also suggests that the legal status of PSCs and PMCs in conflict situations should also be determined on a case-by-case basis and include identification of the client and whether the company should be categorised as a member of an armed force. ${ }^{11}$ Determination of legal status should also include area of operation, since PSC and PMC activities or services will vary in different locations, depending on whether the area of operation is in a conflict zone or in a civil context. ${ }^{12}$ PSC and PMC personnel nationality is also a factor since legal status in international humanitarian law may depend upon the subject's nationality.

In respect of accountability, PSCs and PMCs and their personnel should be subject to prosecution for their wrongdoings, misconduct or crimes, particularly for actions or activities that could be categorised as crimes against humanity or war crimes. While prosecution could occur in courts intheir state of registration, in the contracting state, or in the state where operations are conducted, legal proceedings against PSC or PMC personnel have been rare because of a variety of factors, some legal, and others more practical and political. ${ }^{13}$ Firstly, the contracting state, may give immunity to prosecution to PSCs or PMCs and their personnel. Secondly, the courts may have stopped functioning due to the conflict situation. Thirdly, the contracting and home states may not be able to exercise extraterritorial jurisdiction over PSCs and PMCs because of the absence of national legislation or reluctance to prosecute violations occurring overseas for practical and political reasons. Fourthly, proceedings would be complicated, even if a home or contracting state court is able and willing to do so, because of evidence and witnesses likely to be in another country.

But prosecution of PSCs and PMCs and their personnelcan occur if there is a political will, which will also reduce or eliminate the presumption that the prosecution of private actors cannot be conducted due to a legal vacuum. Theiroversight by a state regulatory body, the insertion of human rights

Katherine Fallah,"Corporate Actors: the Legal Status of Mercenaries in Armed Conflict", International Review of the Red Cross, Vol. 88, No. 863, September 2006, p. 602.

University Centre for International Humanitarian Law Geneva, "Expert Meeting on Private Military Contractors: Status and State Responsibility for Their Actions", http://www.geneva-academy.ch/docs/expert-meetings/2005/2rapport_compagnies_privees.pdf, accessed on 30 August 2005, p. 62.

10 Sarah Parker, "Handle with Care: Private Security Companies in Timor-Leste", http://www.timor-leste-violence.org/pdfs/Timor-LesteViolence-Private-Security-Companies.pdf, accessed on 30 June 2014.

11 Emanuela-Chiara Gillard, "Business Goes to War: Private Military/Security Companies and International Humanitarian Law", International Review of the Red Cross, Vol. 88, No. 863, September 2006, p. 539.

12 Statement 24 and Explanatory Commentary Montreux Document on Pertinent International Legal Obligations and Good Practices for States related to Operations of Private Military and Security Companies during Armed Conflict, 2008.

13 Emanuela Chiara Gillard, Op.cit., p. 543. 
obligations into company contracts and a licencing mechanism are ways to ensure these companies respect of legal obligations and human rights. ${ }^{14}$

\section{Contracting PSCs and PMCs}

Avant suggests that governments hire PSCs and PMCs for a number of differing reasons, such as:

\section{a. Surge and Flexibility}

PSCs and PMCs have the capability to quickly recruit the necessary personnel and to deploy them to an operational area, without any delaying political or bureaucraticobstacles or intervention. Once theoperation is complete, they can quickly conclude the contract and extract the personnel. This capacity enables the contracting state to avoid the likely slow and cumbersome processes it would otherwise face in deploying and standing down its own large military force. ${ }^{15}$

\section{b. Specialized skills}

PSCs and PMCs, through their databases or direct recruitment, can provide the contracting government with specialised personnel with particular skills matching operational requirements or needs. This matching process can be much harder to effect and more complex if conducted by the bureaucratic machinery of the government itself. ${ }^{16}$

\section{c. Decreased political costs}

There is less political damage for the contracting stateif it does not appear to be directly conducting an operation. ${ }^{17}$

However, Avant also states that PSCand PMC utilisation has costs and risks for a contracting state, namely practical problems, and political risks. The practical problems encompass:

\section{a. Cost}

PSCs and PMCs contracting cost is influenced by such factorsas the uncertain and dangerous environment in which a company is, or will be, operating, the current market forces for skilled personnel, and company insurance rates. ${ }^{18}$ Hence, there is potential for PSCs and PMCs to become more expensive than national armed forces in certain situations, particularly where a contracting state is primarily interested in outcomes rather than costs.

\section{b. Reliability}

Efforts by the contracting state to minimize costs may adversely affect the quality of PSC and PMC services, as the contracted companies endeavour to deploy fewer skilled personnel or otherwise reduce services. ${ }^{19}$

\section{c. Integration}

PSCs and PMCs can hinder unified responses to dangerous conditions which can generate conflict with domestic military forces, particularly with uncertainty over rules of engagement, absence of shared knowledge of armed movements, and lack of communication over missions. Furthermore, PSCs and PMCs changing terms of contracts in areas of operationbecome problematic if military field commanders lack direct authority over PSC and PMC personnel. Field commanders may face difficulties coordinating and changing PSC and PMC services in order to meet more immediate operational requirements. These difficulties can be exacerbated by poor coordination between various government departments with separate responsibilities relating to PSC and PMC contracts and operations. ${ }^{20}$

\section{d. Legal uncertainty}

The use of PSCs and PMCs gives rise to issues relating to accountability because of the lack of certainty over theirlegal status - including whether

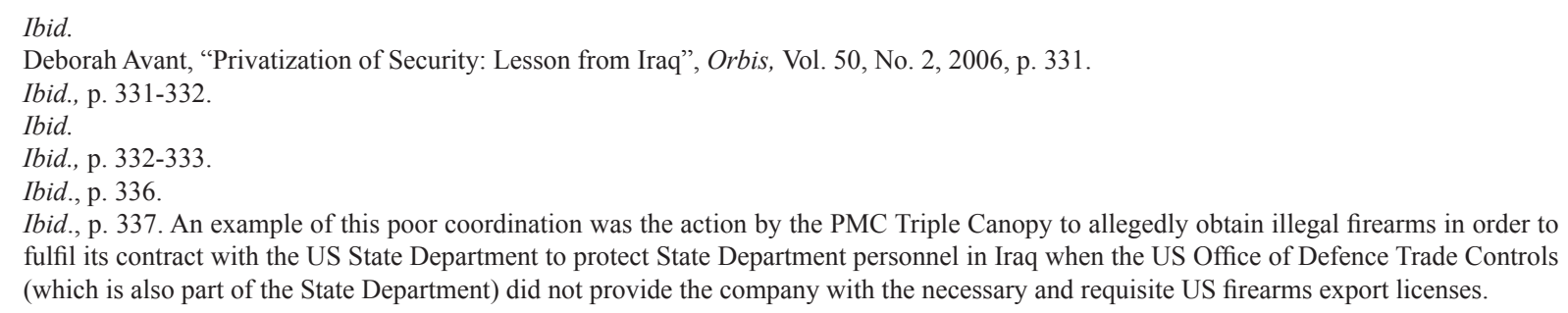

Ibid., p. 337. An example of this poor coordination was the action by the PMC Triple Canopy to allegedly obtain illegal firearms in order to fulfil its contract with the US State Department to protect State Department personnel in Iraq when the US Office of Defence Trade Controls (which is also part of the State Department) did not provide the company with the necessary and requisite US firearms export licenses. 
they can even be subject to certain national laws or rules. For example, PSCs and PMCs contracted to the US Government and operating in Iraq can enjoy immunity generally under the Status of Forces Agreement (SOFA) between the United States and Iraq. ${ }^{21}$

Accordingly, PSC and PMC personnel coming within the provisions of the SOFA have not been subject to Iraqi laws in respect of their contractual activities:

Contractors shall not be subject to Iraqi laws or regulations in matters relating to the terms and conditions of their Contracts, including licensing and registering employees, businesses and corporations; provided, however, that Contractors shall comply with such applicable licensing and registration laws and regulations if engaging in business or transactions in Iraq other than Contracts. ${ }^{22}$

Avant's political risks cover includes the following issues: ${ }^{23}$

\section{a. Military Profession}

Deployment of military forces can be very costly or even ruinous for a fragile economy, and outsourcing may be seen as a way to avoid such financial burden. However, PSC and PMC use may undermine the military and its professional capabilities and ethos. Furthermore, the PSC and PMC sector may cause a negative retention impact on the military, possibly pressuring military leadership to compete with PSCs and PMCs.

\section{b. Democratic Restraint}

Utilising PSCs and PMCs may lead to the reduction of transparency, with a consequent negative political impact on government policy and undermining of the capacity to hold governments accountable for their decisions and actions.

Wing suggests that PSCs and PMCs can grow and expand their activities because governments, particularly western governments, are unwilling to face political backlash by exposing their armed forces personnel to risk of death and injury. ${ }^{24}$ Luttwak suggests that, although the public generally approve of the armed forces, they oppose family members in combat situations in which death and injuryare occupational hazards. ${ }^{25}$ Thus, PSC and PMC utilisation may be a solution for a government as an alternative to national armed forces deployment.

The presence of these companies in a country can be attributed to several factors, such as opportunity for economic gain, unstable conditions, and lack of regulatory legal instruments (described by Faite as the 'legal vacuum'). ${ }^{26}$ Opportunity for economic gain can be the main reason for PSCs to conduct operations in a country. ${ }^{27}$ Pay rates available to PSC and PMC personnel can be significantly higher than those in national armed forces, and thus an attraction for former military personnel to join the companies. ${ }^{28}$ Since PSCs and PMCs are hired to provide security, they may have little interest in

21 See Article 12 Agreement between the United States of America and the Republic of Iraq on the Withdrawal of United States Forces from Iraq and the Organization of Their Activities during Their Temporary Presence in Iraq, 17 November 2008.

Coalition Provisional Authority Order Number 17 (Revised), S. 4 (2) (Iraq).

Deborah Avant, "Privatization of Security: Lesson from Iraq", Orbis, Vol. 50, No. 2, 2006, p. 340.

24 Ian Wing, "Private Military Companies and Military Operations", Australian Army Land Warfare Studies Centre, Paper No. 138, October 2010, p. 19.

25 Edward Luttwak, "Where are the Great Powers", Foreign Affairs, Vol. 73, No. 4, 1994, p. 25.

26 Alexander Faite, "Involvement of Private Contractors in Armed Conflict: Implication under International Humanitarian Law", Defense Studies, Vol. 4, No. 2, 2004, p. 12.

27 For example, the US Congressional Budget Office estimated that the US Government expended \$6-10 billion on PSCs and PMCs during 2003 - 2007, and specifically allocated \$3-4 billion for PSC and PMC operations in Iraq, see Congress of The United States Congressional Budget Office, "Contractor's Support of U.S. Operations in Iraq", http://www.cbo.gov/sites/default/files/08-12-iraqcontractors.pdf, accessed on 2014. In 1997, the PMC Sandline received contracts worth around \$36 million from the Papua New Guinea government for its first three months, and \$45 million in its first year of operations; in Africa, the PMC Executive Outcome earned \$55 million between 1998 and 2002, not including its Sierra Leone contract which was worth an extra $\$ 1.8$ million per month. See also Sam Vaknin, "Private Armies", http://www.sandline.com/ hotlinks/private_armies.html, accessed on 30 June 2014.

28 Ian Wing, Op.cit., p. 17. For example, in Iraq during 2003 US, UK and Australian PSC and PMC personnel with "special forces" expertise, could expect to receive around US\$2000 per day, although this could eventually reduce to \$700 per day. On the other hand, PSC and PMC personnel from non-Western countries and Iraqi personnel might be paid around US\$50 per day for similar tasks. 
ending a conflict or improvinga security situation, since this would cause their personnel to lose a lucrative source of income or other financial return.

Instability conditions caused by civil unrest, internal conflicts, or breakdown of state law and order can create an environment conducive for PSC and PMC operations. This situation usually occurs in conflict or post-conflict countries where governments cannot maintain their own security, thereby enabling PSCs and PMCs to deliver that security requirement. The combination of unstable conditions and economic gain can occur in particular in a country which has vast deposits of natural resources by providing opportunity for further PSC or PMC wealth generation through the granting of licences, concessions or sale over those resources as payment in kind for security services.

A legal vacuum can also be an attraction for PSC and PMC operation since the lack of legislation or regulation enables them to operate without restraint. Even where a law or regulation does exist, implementation may be non-existent due to inadequacies in the enforcement regime or the government of the state grants immunities to the PSC or PMC operate in the country.

\section{PSC and PMC Presence in Timor-Leste}

Timor-Leste, as a post-conflict nation, provides a useful case-study of the operation of PSCs and PMCs. Ithas experienced major episodes of violence and civil unrest - both before and after independence in May 2002. These episodes required international peace-keeping interventions in 1999 and again in 2006. The government has been able to provide only uncertain and limited security, and this has created a demand for the services of PSCs and PMCs. Additionally, Timor-Leste's huge deposits of natural resources, especially oil and gas, have attracted many international companies - companies which are liable to become clients of PSCs and PMCs in light of the country's fragile security situation.

Timor-Leste's security situation and the presence of international peace-keeping forceshavemade it an attractive environment for PSCs and PMCs. A growing number of PSCs are operating in Timor-Leste, and providing security services such as protection to various embassies, international agencies, government institutions, commercial and business premises, and private residences. They also provide secure money movement, security alarm systems and mobile rapid response, private investigation; and supply various forms of equipment to government institutions, including the Timor-Leste National Police (PNTL) and the Timor-Leste Defence Force (F-FDTL). While PSC personnel do not carry fire arms on operations, on occasion they carry non-lethal equipment, such as pepper spray, tasers and rubber batons.

The majority of security-related companies operating in Timor-Leste are PSCs, since most of the services and day-to-day operations are more in the context law enforcement support rather than military operations. However, PMCs have also operated in the country and will likely continue to do so in the future.

Table 1. Local PSCs Operating in Timor-Leste

\begin{tabular}{|c|c|c|c|c|}
\hline Company & $\begin{array}{c}\text { Management } \\
\text { Origin }\end{array}$ & Commenced & Services & Numbers \\
\hline $\begin{array}{l}\text { Maubere Security } \\
\text { (Formerly Chub } \\
\text { Security) }\end{array}$ & $\begin{array}{l}\text { Timorese and } \\
\text { Australian }\end{array}$ & 2004 & $\begin{array}{l}\text { Civil security, electronic } \\
\text { security, cleaner, fire } \\
\text { extinguishing services. }\end{array}$ & 1,300 \\
\hline
\end{tabular}




\begin{tabular}{|c|c|c|c|c|}
\hline Gardamor & Timorese & 2007 & $\begin{array}{l}\text { Civil security \& protection, } \\
\text { close investigation, secure } \\
\text { asset transfer, body } \\
\text { guards, fire protection \& } \\
\text { evacuation, cooperating with } \\
\text { PNTL\&Timorese Fire Brigade. }\end{array}$ & 2,500 \\
\hline $\begin{array}{l}\text { APAC Security } \\
\text { (formerly } \\
\text { Seprositil) }\end{array}$ & Australian/US & 2007 & $\begin{array}{l}\text { Security guarding (including } \\
\text { close protection), emergency } \\
\text { response, asset transport, } \\
\text { security consultation. }\end{array}$ & 2,000 \\
\hline $\begin{array}{l}\text { High Risk Security } \\
\text { Group (Asia- } \\
\text { Pacific) }\end{array}$ & Australian & 2004 & $\begin{array}{l}\text { Risk mitigation, physical \& } \\
\text { close personal protection, } \\
\text { premium guard services, aero- } \\
\text { medical evacuation, paramedic } \\
\text { services, security risk } \\
\text { assessment, logistics, security } \\
\text { awareness training, specialist } \\
\text { security and law. }\end{array}$ & $51-300$ \\
\hline Gear Defence & Timorese & 2009 & $\begin{array}{l}\text { Equipment supply to } \\
\text { government departments. }\end{array}$ & +300 \\
\hline
\end{tabular}

Source: Compiled by the author.

PSC presence in Timor-Leste has the capacity to produce two different results affectingnational security and recovery. Firstly, their presence may cause conflict and friction with the PNTL or the F-FDTL. This could happen where the Timorese population views PSCs or PMCs as providing security more effectively and efficiently than the PNTL or F-FDTL. ${ }^{29}$

Additionally, since PSC contracts are far too costly for much of the Timor-Leste population, those who live near or below the poverty line cannot access their security services. Consequently, if friction occurs between these socio-economic groups, PSCs can become involved in horizontal (class/economic) conflicts when acting on behalf of their wealthy clients. ${ }^{30}$

PMC presence in Timor-Leste does not attract much public attention, although some companies, such as the US-based DynCorp International, have played an increasing role in Timor-Leste's post-independence period. DynCorp, for example, provided helicopter and satellite network communications support for the UN peacekeeping forces. ${ }^{31}$ The company currently maintains a very low profile locally and hence it is difficult to gain any confirmation on its current operations and activities. Itmightoperate inside the country in future as part of a visiting international force, as part of a foreign diplomatic corps, or under contract from the TimorLeste government itself.

Table 2. Foreign PSCs and PMCs Operate in Timor-Leste

\begin{tabular}{cclcl}
\hline Company & $\begin{array}{c}\text { Company } \\
\text { Type }\end{array}$ & \multicolumn{1}{c}{ Country } & Commenced & \multicolumn{1}{c}{ Services } \\
\hline Onix International & PSC/PMC & $\begin{array}{l}\text { New } \\
\text { Zealand }\end{array}$ & Since 2000 & Hostage Rescue Operation
\end{tabular}

\footnotetext{
Nelson Belo, “Saida Mak Akontese Ba Kompaña Siguransa Privadu iha Futuru?”, Fundasaun Mahein, Vol. 27, No. 1, 2011 , p. 1.

Sarah Parker, Loc.cit.

Peter Singer, 2003, Corporate Warriors: The Rise of the Privatized Military Industry, Cornell University Press, New York, p. 14.
} 
$\begin{array}{llll}\text { DynCorp } & \text { PMC } & \text { US } & \text { Since } 1999 \\ \text { International } & & \end{array}$

Supporting UNTAET

administration \& peacekeeping;

US Forces operations in Timor-

Leste; services to Timor-Leste

Government - PNTL training,

F-FDTL logistic support,

$\&$ assisting anti-corruption

campaign.

\begin{tabular}{llll}
\hline Academia (Formerly & PMC & US & Exact year of \\
Blackwater & & & first operation \\
International & & & uncertain \\
\end{tabular}

Exact activities in Timor-Leste

unidentified.

Xe Service)

Source: Compiled by the author.

There are reports of PSCs and PMCs in a country being accused of committing serious violations of laws or even basic human rights during their operations; for example, DynCorp has been the subject of a number of serious allegations. ${ }^{32}$ The prevalence of such reports, even if not always substantiated, reinforces the importance for the Timor-Leste Government to regulate PSCs and PMCs, in order to avoid the grave violations that have allegedly occurred in Bosnia, Iraq and Afghanistan.

\section{PSC and PMC Regulation in Timor-Leste Legal System}

In August 2010, the Timor-Leste Government issued instructions in order to regulate PSCs by way of Secretary of State for Security Instruction No. 03/OSSS/VII/2010 of 6 August 2010 (the "2010 Instruction"). It is the first and only specific regulation regarding the control of PSC activity in Timor-Leste. The Instruction is a remarkably brief document considering the subject matter with which it deals, consisting of only 13 clauses. Some of the clauses are also rather brief, although a few, such as Article 10, include a number of sections and subsections. The Instruction does not cover or even mention PMCs.

\section{Key Provisions of 2010 Instruction}

Article 1of the 2010 Instruction defines PSCs as "Security Companies that provide protection of assets and crime prevention activities, in purpose to gain profit and/or income". ${ }^{33}$ It does not provide any further clarification as to what constitutes a PSC. Articles 2 and 5 detail PSC activities and duties, which include: ${ }^{34}$
a. $\quad$ protection for dynamic and static assets;
b. monitoring the presence and in-out movement of people;
c. prevention of firearms smuggling or use of prohibited materials or equipment that could be used to incite/ create violence; and
d. prevention of activities involving assets, properties, buildings, or locations that could result in their closure to the public.

At the same time, Article 3 prohibits PSCs from conducting certain operations, such as ${ }^{35}$

\footnotetext{
32 Allegations against DynCorp include: uncontrolled aerial spraying of herbicides and fumigants in the border region between Colombia and Ecuador to eradicate Colombian cocaine and poppy plantations, but which also caused severe health problems, and plant, crop and livestock destruction, see Verdict No. 1:01-cv-01908-RWR 2 Venancio Aguasanta Arias, et al., v DynCorp, et al., direct involvement in military counter-insurgency operations and anti-drug missions, such as special search and rescue operations and provision of helicopter gunship pilots against Colombian rebel groups and drug cartels. See also Departemen of National Security, 2005, Request for Training Plan and Phaseout Timeline for DynCorp Operations in Colombia, Transportation Security Administration, United States of America, pp. 1-2, involvement in child prostitution and slavery in Bosnia in 1999. See also Martina E. Vandenberg and Kathleen Peratis, "Trafficking of Women and Girls to Bosnia and Herzegovina for Forced Prostitution", Human Rights Watch, Vol. 14, No. 19, 2002, p. 3, and involvement in hiring young boys as child prostitutes in Afghanistan. See also The Guardian, "US Embassy Cables: Afghan Government Asks US to Quash 'Dancing Boys' Scandal", http://www.guardian.co.uk/world/us-embassy-cables-documents/213720, accessed on 30 June 2014.

33 Article 1 DespachoNo. 03/GABSES/VII/2010 de 6 de Agosto 2010, Timor-Leste.

34 Ibid., Article 2 and 5.

35 Ibid., Article 3.
} 
a. prosecutions or any activities within the jurisdiction of the Department of Justice or the PNTL;

b. activities that may threaten, prohibit, or restrict fundamental guarantees and rights; and

c. security services for assets, activities, or persons that may be involved in illegal or criminal activities.

Article 6 also prohibits PSC owners, managers, or employees with fraud-related criminal records being involved in company activities, especially operational activities. ${ }^{36}$

The Instruction requires PSCs to be registered with the State Secretariat of Security. The nature and range of documentation and information required to obtain registration is comprehensive. It includes a provisional license for company and business activities; company address and list of assets; company statute, articles of association or charter; names of company owners and managers, as well as employees and their ranks or positions; design of the company uniform; certification that the PSC is not indebted to the State; copy of the company employee identification card; and company history and security services. ${ }^{37}$ While conducting security services, PSC employees must be in uniform and carry the identification card,and are prohibited from using firearms. ${ }^{38}$

Article 10 of the Instruction requires PSCs and their employees to provide assistance to, and cooperate with, public officials and authorities, ${ }^{39}$ and to place themselves under the latters' command if involved in operational locations. ${ }^{40}$ But all PSC personnel must also ensure that they distinguish themselves and their activities from public officials to avoid confusion by the public. ${ }^{41}$ PSCs and their personnel must keep information relating to their profession confidential, and ensure that it is only disclosed pursuant to the Penal Code and judicial process. $^{42}$

For monitoring purposes, the Instruction provides that PSCs and their activities in TimorLeste fall under the jurisdiction of the Dirasaun Nasional Seguransa Publik DNSEP (Directorate for the National Management of Public Buildings), a department within the State Secretariat of Security. This body is charged with the responsibility of ensuring that PSCs conduct their activities according to the 2010 Instruction, and of maintaining records of those activities and all PSC owners, managers, and personnel. ${ }^{43}$

\section{Deficiencies of $\mathbf{2 0 1 0}$ Instruction}

However, the Instruction has some fundamental deficiencies, since it does not address a number of issues key to PSC operation and supervision, such as:

a. Standard Personnel Recruitment Requirements

The Instruction does not make any specific provision relating to standard requirements for PSC personnel, including training, for registration purposes. Accordingly, requirements differ widely amongst local PSCs. For example, the PSC APAC reportedly requires their personnel to be "over 18 years old, free of communicable diseases, in good physical condition, have completed secondary school, possess basic reading and writing skills, and be fluent in Tetum and/or Indonesian". ${ }^{44}$ Maubere Security, on

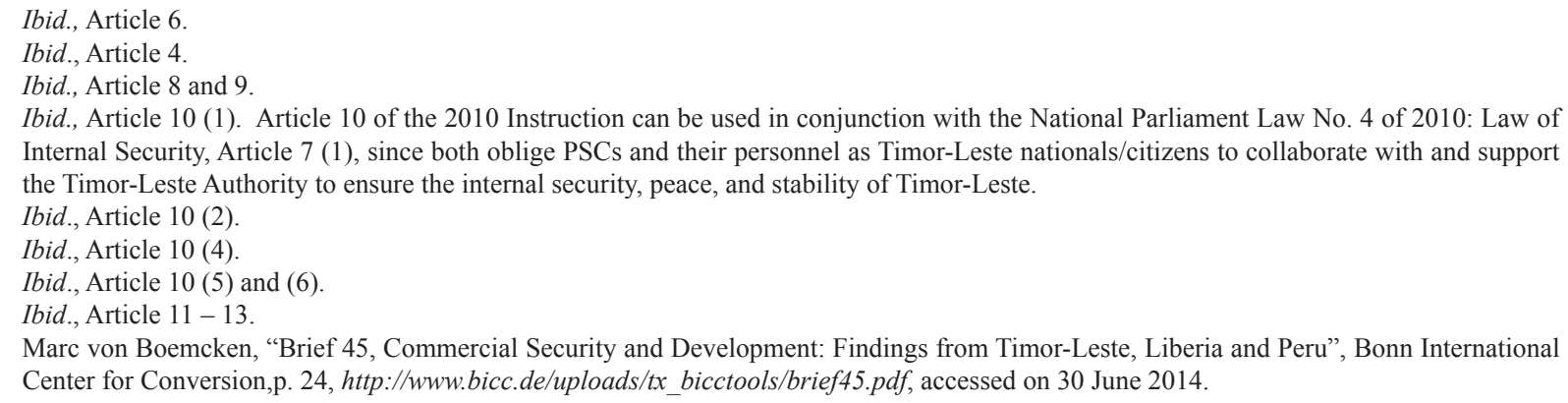


the other hand, reportedly requires their personnel to "have completed senior high school, be at last $160 \mathrm{~cm}$ tall and have some basic knowledge of Portuguese and English". ${ }^{45}$ Maubere also requires personnel undertake "one month's training, which includes the improvement of foreign language skills as well as the basics of customer relations and guarding activities - to be regularly refreshed". ${ }^{46}$

b. Restrictions on Affiliation with Certain Political Parties, Organisations, or Groups

Provisions prohibiting PSC affiliation with certain political parties, organisations, or groups is very important because of the existence of organisations and groups with heterogeneous backgrounds, in particular political backgrounds, amongst the Timor-Leste population. The Instruction does not make any provision or prohibition in respect of PSC involvement with political parties or other organisations whose intentions or activities may be directed towards a destabilisation of the present political, economic or social order. Hence there is no requirement for PSCs to remain neutral and independent without any affiliation to political organisations or groups.

c. Prohibitions on Mercenary-Related and Subversive Activities

Mercenary-related, subversive or other activities by PSCs and PMCs that could threaten the national integrity can constitute a major threat for TimorLeste. Again, the Instruction does not contain any provision relating to such activities.

\section{d. PSC Uniforms}

While the Instruction requires PSC personnel on operation to be uniformed, it makes no further stipulation in respect of their design or form. Since those used by a number of PSCs are similar in colour and design to the PNTL uniforms, confusion can arise amongst the Timorese in differentiating between PNTL officers and PSC personnel. ${ }^{47}$

\section{e. Accountability and Sanctions}

The Instruction does not include any provisions relating to PSC accountability. Nor does it describe In any detail what may constitute an infringement or violation of the Instruction, except by implication of non-compliance. Accordingly, the Instruction does notprovide for any sanctions for non-compliance, infringement or violation.

\section{f. PMC Regulation}

The Instruction does not regulate PMCs or even mention them. This is understandable since the Instruction is specifically designed for PSCs. However it raises concern that PMC operation in Timor-Leste is conducted entirely in a legal vacuum.

Despite these deficiencies, the 2010 Instruction can be viewed as a reasonablycompetent attempt to regulate PSCs, since the absence of reports of infringements of the Instruction by PSCs would seem to indicate the companies' general compliance. However, it is suggested that infringements do occur since there are many criminal violations in Timor-Leste, including some committed by PSC personnelthat remain unreported or are simply not documented.

As stated by a representative of DNSEP ${ }^{48}$ and endorsed by the Secretary of State for Security, ${ }^{49}$ the 2010 Instruction is intended as a temporary regulation until replaced by a proper and adequate statute. Regardless, the Instruction itself has an important role as it prevents a legal vacuum for issues relating to PSCs within the Timor-Leste legal system.

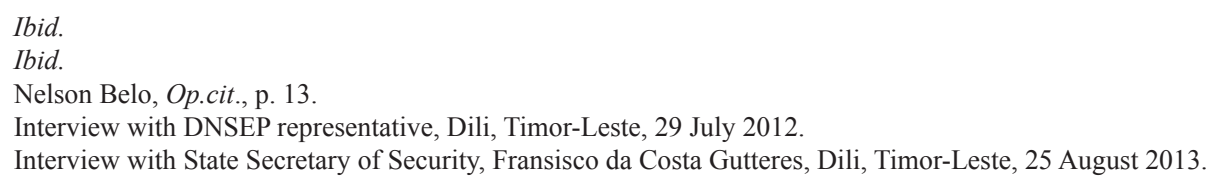


The Timor-Leste Parliament is currently debating a new legal framework for governing of PSCs and their activities in Timor-Leste. ${ }^{50} \mathrm{~A}$ future statute needs to both develop from the 2010 Instruction and address its deficiencies. Additionally, it may draw upon international initiatives on PSCs and $\mathrm{PMCs}^{51}$ and the national laws of the United States, the United Kingdom, South Africa, Iraq, Afghanistan, and Indonesia as countriesin which PSCs and PMCs have operated, or have suffered from unstable security conditionsand violence, or have used PSCs and PMCs to support armed forces operations overseas.

\section{A Future PSC and PMC Statute}

The exact form of Timor-Leste'sfuture statute is still undetermined; but because the drafting is being conducted within the Parliamentary context, it will probably be produced as an act of Parliament. This will give the statute much greater status and legal force than a Ministerial instruction or other delegated instrument. It is suggested that the Parliament has two options - to create a single statute that covers both PSCs and PMCs, or to create two separate statutes. Many of the core PSC and PMC provisions are similar in principle, but there are also essential and substantive differences between them.

\section{a. Definition of The Company, Its Personnel and Services}

A future statuteneeds to provide clear definition of a PSC, a PMC, and their legitimate activities, in order to establish a better understanding of their purpose and roles, and provide some parameters and limits for their necessary monitoring and regulation.However, the difference in the definition ofservices is that those provided by a PSC must be in the nature of contributing to law enforcement and crime prevention and available to any entity in Timor-Leste, including organs of the state. PMC services, on the other hand,are more in military in nature and can only be provided to the Timor-
Leste Government.

Even though these definitions are stillfar from satisfactory, at least theymay give some understanding of the nature and activities of both PSCs and PMCs for government officials and the Timor-Leste population in preventing the overlapping of tasks between the two types of companies.

\section{b. The PSC and PMC Regulatory and Monitoring Body}

In some respects, the PSC and PMC regulatory and monitoring bodies will have a very similar function, namely, to control and manage the companies and their activities within Timor-Leste. The bodies will provide company and individual personnel registration procedures including approval, renewal, revocation, refusal and modification, in order to produce operating licenses for both the companies and their personnel. Within the statute parameters, these bodies can determine permitted and prohibited PSCs and PMCs activities. The bodies can also establish a reporting and complaints mechanisms.

However, reflecting differences in their core activities, PSC and PMCs may well require separate regulatory and monitoring bodies. Assuming separate bodies are established, the Timor-Leste Government could appoint the National Management of Public Security (Dirasaun Nasional Seguransa Publik-DNSEP) as the regulatory and monitoring body for PSCs. This is the most logical option since the DNSEP already supervises and manages PSCs. It would also be logical to establish the separate PMC regulatory body under the authority of the State Secretariat of Defence, since Defence has both experience and responsibility for any military activities inside the country. This placement also reflects the military and

50 Interview with State Secretary of Security, Fransisco da Costa Gutteres, Dili, Timor-Leste, 23 August 2013.

51 Such as the Montreux Document on Pertinent International Legal Obligations and Good Practices for States Related to Operations of Private Military and Security Companies During Armed Conflict and the International Code of Conduct for Private Security Services Providers. 
paramilitary nature of PMCs.

\section{c. Registration of PSCs and PMCs}

The PSC regulatory and monitoring body provides company and individual registration, an essential pre-requisite 1 to obtain the licenses required to operate in Timor-Leste. There is currently no separate registration process for a PMC (unless as a PSC). The current PSC registration process requires a Commercial Licence for company activities, issued by the National Directorate for Registration and Notarial Offices of the Ministry of Justice, ${ }^{52}$ and a License for Economic Activities, ${ }^{53}$ issuedthe by Ministry of Commerce, Industry and Environment. To obtain these licenses PSCs need to first register with the National Directorate and the Ministry.

Being inter-departmental, this registration process is very complicated and time consuming and can cause confusion as to which institution is the 'proper' regulatory body for PSCs in Timor-Leste. Efficient, effective regulatory and monitoring practice and ease of operation for all parties will follow if the one body is responsible for monitoring, for registration and for the issuance of the necessary operating licences.

For registration, where none currently exists, a PMC should be required to obtain authorisation and an operating license from its own regulatory and monitoring body in order to conduct operations. The operating license must encompass the following conditions and information:

1) PMC services to be limited to Timor-Leste only;

2) PMC personnel and subcontractors involved in the contract;

3) registration of individual PMC personnel;

4) registration of equipment, including firearms, to be used.

Since PMC registration includes firearms and other weapons directly supporting the company's services and activities, it can be also be utilised as a preventive measure against equipment that could be used to hinder the stability and security of the country, illegal weapons or firearms transfer, and as a control on the types and quantity of weapons that might imported, acquired and used by PMCs in an area of operation.

\section{d. Registration of PSC and PMC Personnel}

Individual registration of PSC and PMC personnel complements company registration and is a key element in the proper regulation and monitoring of PSC and PMC activity. Individual registration should require that the applicant:

1) be a Timorese citizen, at least 18 years of age (being minimum adult age under Timor-Leste law), and physically and mentally sound;

2) have complied with the training requirements prescribed for registration;

3) have not been under investigation for a crime or found guilty or improper conduct under any applicable Timor-Leste regulation;

4) not currently be a member of the PNTL or the F-FDTL.

PMC individual registration should further require details of nationality, country of origin, background ${ }^{54}$ and evidence of no

\footnotetext{
See Código de Registo Comercial (aprovado pelo Decreto-Lei $n^{\circ} 7$ of 2006 de 1 de Março de 2006), Preamble 1.

Background checks will require no criminal record or involvement in crimes committed in another country or categorised as violations or grave breach of international law; no record of misuse/abuse of alcohol, drugs, or other illicit substances. It will also require any record of military training or service, PMC service training, and weapons and firearms training.
} 
current active membership of publicsecurity, military, intelligence, or secret services of a foreign country.

\section{e. Determination of PSC and PMC Services}

Whether the government opts for the aforementioned single-statute option or the dual-statute option, the legislative framework must draw a clear distinction between PSC and PMC services and those that are the responsibility of the public security forces, the judiciary or the defence forces. For example, PSCs and PMCs cannot be permitted to conduct any activities relating to criminal prosecution or activities that restrict personal freedoms, including basic human rights. In addition, both should be prohibited from providing or making their services available to any parties involved in criminal activities.

The future statute should also prohibit PSC or PMC affiliation with certain political parties, organisations, or groups - a particularly important provision in the current fragile security situation in the country and the prevalence of hostility between organisations and groups within the population. Such provision will contribute significantly to the reduction or elimination of conflicts of interest that otherwise exist and could continue to occur within PSCs and PMCs. A similar practice has occurred in Ecuador where PSCs have become a stop-gap measure to provide assistance to the police forces until the police forces have sufficient numbers and capacity for the enforcement of law and order and public security. ${ }^{55}$

However, PSC personnel must distinguish themselves and their activities from the public officials to avoid public
confusion.The PSC future statute or PSCspecific provisions must mandate that PSCs and their personnel shall cooperate with, and provide assistance to, public security and law enforcement officials and authorities, and to place themselves under the latters' command in the event of intervention in operation locations. One element of the provision of assistance and cooperation includes maintenance of confidentiality of information obtained in the course of their professional activities, but also disclosure of such information to authorities in accordance with the Timor-Leste Penal Code.The PMC future statute or $\mathrm{PMC}$-specific provisions may not include similar provision in respect of giving assistance and cooperation to the civilian authority.

Peculiar to the PMC future statute or PMC-specific provisions should be requirements that $\mathrm{PMCs}$ are prohibited from conducting activities exclusively the responsibility of the F-FNTL, such as direct participation in armed conflict that may occur inside Timor-Leste or any activity to maintain national defence.

\section{f. PSC Uniforms}

The future statute must contain more detailed provisions on uniforms than those currently in the 2010 Instruction. ${ }^{56}$ There are several reports of PNTL officers assaulting PSC employees wearing similar uniforms to the PNTL. ${ }^{57}$ Because of the PNTL actions, PSC personnel choose to remove their uniforms while on duty and wear plain clothes so as to avoid such problems with the PNTL. ${ }^{58}$ This in turn makes it even more difficult to distinguish PSCs employees from the civilian population.

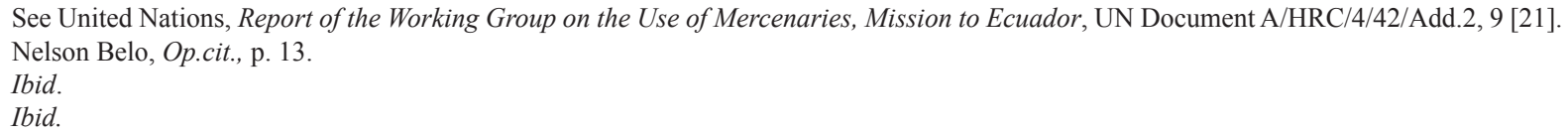




\section{g. PSC and PMC Accountability and Sanctions}

Both PSCs and PMCs, as private companies, have responsibilities and obligations under Timor-Leste laws, the laws of the countries where they operate, and the laws of the country of origin of their personnel..$^{59}$ Hence both companies and their personnel should be held accountable under the future statute for any wrongdoing under Timor-Leste law, whether they themselves commit the wrongdoings or encourage, order, or assist others to do so. ${ }^{60}$ In particular, PSC owners and management must also be held accountable, since they have capacity to direct personnel and control them legally and financially. ${ }^{61}$ They should also be held accountable for failure to take necessary measures to prevent wrongdoings where they know or culpably ought to have known of potential or actual wrongdoings. ${ }^{62}$ The accountability need not be limited to the PSC itself but might also be attributable to its clients, where the wrongdoing was committed on behalf of or acknowledged by its clients or under client contracts.

The future statute could follow the example of the South African regulation on accountability and sanctions for any transgressions and breaches of statutory instructions. Transgressions could include conspiracy, incitement or attempt to commit a transgression. ${ }^{63}$

PSC and PMC sanctions generally could be similar. They can include temporary or permanent revocation or suspension of company registration and license, financial penalties or imprisonment or a combination thereof, in accordance with the Timor-Leste Penal Code and other national laws. But there are additional sanctions for established PMC wrongdoings, such as contract termination, prohibition on future contracts, visa cancellationsand deportation. Irrespective of whether the available sanctions apply to one or both PSCs and PMCs, they must be of sufficient gravity and severity to act as a deterrent.

\section{Facing Challenges}

Enacting a legal framework for PSCs and PMCs will be challenging, since the Timor-Leste Government still faces major issues of weak institutional capacity in areas of parliamentary activity and rule of law. Allegations regularly arise of some members of Parliament misusing their positions, and of widespread levels of corruption and nepotism inside public institutions. ${ }^{64}$ In addition, a general lack of understanding about PSCs and PMCs has potential to frustrate attempts to make appropriate regulation for the companies. Parliament may have some understanding of PSCs since Timor-Leste has regulated the PSC industry within its legal system. But it is a different situation with respect to PMCs, since Parliament is unlikely to understand the company and the services it might offer. Accordingly, there are grounds for concern that Parliament may be unable to enact an appropriate legal framework for PSCs and PMCs for these reasons.

The implementation of the future statute will also presentmajor challenges. Enforcement will be difficult and problematic if government departments

Emanuela-Chiara Gillard, Op.cit., p. 546.

Chia Lehnardt, "Individual Liability of Private Military Personnel under International Criminal Law", European Journal of International Law, Vol. 19, No. 5, 2008, p. 1022.

Ibid., pp. 1027 and 74.

Ibid., p. 1028.

For example Chapter 3 (26) number (1) alphabet (a) and (b) Private Security Industry Regulatory Act No. 56 of 2001 , South Africa.

See US Agency for International Development, "Corruption Assessment: Timor-Leste", http://pdf.usaid.gov/pdf_docs/PNADQ697.pdf, accessed on 30 June 2014. See also East Timor Law and Justice Bulletin, "Prime Minister Gusmao Lashes out at Anti-Corruption Commission", http://www.easttimorlawandjusticebulletin.com/2013/04.html, accessed on 13 April 2014. 
lack adequate knowledge and understanding about the future statute, and about PSCs and PMCs. Similar difficulty can also occur with judicial institutions and Timor-Leste society generally. Inadequate knowledge and understanding within judicial institutions will adversely affect their ability to properly deal with crimes or misconduct by PSCs and PMCs. Timor-Leste society, as part of a wider societal monitoring mechanism of PSCs and PMCs, may be unable or unwilling to provide information onPSC and PMC activities and operations when they do not understand the future statute and the organisations involved. In order to deal with such difficulties, dissemination of information on the future statute, and on PSCs and PMCs needs to be conducted at all levels of Timor-Leste society.

Lack of resources can also become an obstacle in the enforcement of the future statute, particularly human resources and facilities that support enforcement. Furthermore, they need to be supported with sufficient equipment in order to conduct the enforcement activities.

Politicisation and abuse of power in government institutions, as has occurred in the police and defence forces by some political leaders in order to achieve their own political objectives, can hinder implementation of the future statute. ${ }^{65}$ Misuse of authority can circumvent a future statute, as shown in Afghanistan when President Karzai circumvented his own decree for the benefit of his brother's PSC. ${ }^{66}$ Such improper intervention in government institutions dealing with PSCs and PMCs will disturb the proper implementation and enforcement the statute. It may also exacerbate corruption, since such political intervention is solely directed towards their own financial gain.

Even though the implementation of the future statute may face these issues, it can still be implemented and followed by the companies concerned. PSCs appear to have reasonably complied with the 2010 Instructionin general since there are no confirmed reports of any grave violations by them. This past performance gives grounds for confidence that the statute is likely to be followed by PSCs and PMCs in similar fashion.

Even where implementation challenges exist, there are also ways to overcome them. First, an education strategy for government officials, non-government organisations, and business and industry, which would include training programs regarding PSCs and PMCs, is essential in order to provide a proper understanding and knowledge relating to these companies and their operations. The strategy should include the PSC and PMC legal framework, the nature, function and activities of PSCs and PMCs, and how they are equipped and operate in their areas of operation, and so forth.

Second, clear and comprehensive instructions and regulations will also reduce the possibilities and likelihood of government officials acting with politicised motives and misusing authority, by giving notice to all that non-adherence will constitute a breach and that stipulated consequences follow.

Third, the availability of policies and guidelines through print and electronic media regarding PSCs and PMCs will enable the TimorLeste population to be informed about these companies, and their operation and regulation. This will improve the informal monitoring role that the population can play in respect of the companies and their operations. In addition, these policies and guidelines can become social control tools for the government when it has enacted and implemented the PSC and PMC legal framework properly.

Fourth, the government must allocate funding to improve and provide the required facilities and personnel until they reach an appropriate quantum to support the effective implementation and enforcement of the PSC and

65 Security Sector Reform Resource Centre, "Country Profile: Timor-Leste", http://www.ssrresourcecentre.org/wp-content/uploads/2010/04/ Country-Profile-Timor-Leste-April-7.pdf, accessed on 30 June 2014.

66 See Nadene Ghouri, "How to Make a Killing in Kabul: Western Security and a Crisis in Afghanistan", http://www.dailymail.co.uk/home/ moslive/article-1360216.html, accessed on 30 June 2014 
PMC legal framework. An appropriate source of funding for these initiatives would be ministerial operational budgets, in particular from the Ministry of Defence and Security or the Ministry of Justice. Another option can be from the Petroleum Fund whichderives revenues from the Timor Gap oil and gas fields royalties.

However, both options also present difficulties. Allocation of funding from both Ministries' operational budgets and the Petroleum Fund needs to be approved and regulated within the annual state budget by Parliament. Unless funding has been so approved and regulated for the fiscal year, it may become just one of many priorities of the related ministries, and subject to competition from other projects, external pressures and lobbying. Unless Parliament sets funding, the PSC and PMC legal framework implementation will suffer from paucity of effective decision-making and funding.

\section{Conclusion}

The presence in Timor-Leste of PSCs, and to a lesser extent PMCs, has brought some positive developments to domestic commerce, industry and society. The companies have contributed to the recovery efforts of Timor-Leste, ranging from providing logistical support to providing workplace opportunities that have helped to reduce the national unemployment rate. Furthermore, the companieshave had a big impact on the security development of Timor-Leste since they have been variously a stop-gap, or a support, or a supplement for the PNTL, while that body has attempted to build its capacity and capability to conduct effective and comprehensive security operations.

The contribution of PSCs can be seen in the area of economic and social development. With Timor-Leste having an unemployment rate around $18.5 \%$, PSCs are one of the largest job providers in the state, and a growing business sector which contributes to reducing the rate of unemployment amongst the Timor-Leste population. They have not posed a threat to human rights and appear to have been generally law abiding. ${ }^{67}$

The Timor-Leste government views PSCs as having an important role in continuing to contribute to the maintenance of law and order through positive relations and cooperation with government agencies, since both share the same objective of providing and guaranteeing security to society. ${ }^{68}$ However, they still need to be regulated and managed within an appropriate framework as part of theTimor-Leste legal system. Control and proper management is essential for continuation of their positive contributions towards the prevention of conflict and the promotion of peace and stability in re-building the country.

\section{REFERENCES}

\section{A. Books}

Departemen of National Security, 2005, Request for Training Plan and Phaseout Timeline for DynCorp Operations in Colombia, Transportation Security Administration, United States of America.

Singer, Peter, 2003, Corporate Warriors: The Rise of the Privatized Military Industry, Cornell University Press, New York.

\section{B. Journals Articles}

Faite, Alexander, "Involvement of Private Contractors in Armed Conflict: Implication under International Humanitarian Law", Defense Studies, Vol. 4, No. 2, 2004.

Lehnardt, Chia, "Individual Liability of Private Military Personnel under International Criminal Law", European Journal of International Law, Vol. 19, No. 5, 2008.

\footnotetext{
67 Marc von Boemcken, "Brief 45, Commercial Security and Development: Findings from Timor-Leste, Liberia and Peru", http://www.bicc.de/ uploads/tx_bicctools/brief45.pdf, accessed on 30 June 2014

68 See Nelson Belo, Loc.cit.
} 
Avant, Deborah, "Privatization of Security: Lesson from Iraq", Orbis, Vol. 50, No. 2, 2006.

Luttwak, Edward, "Where are the Great Powers", Foreign Affairs, Vol. 73, No. 4, 1994.

Gillard, Emanuela Chiara, "Business goes to War: Private Military/Security Companies and International Humanitarian Law", International Review of the Red Cross, Vol. 88, No. 863, September 2006.

Wing, Ian, "Private Military Companies and Military Operations", Australian Army Land Warfare Studies Centre, Paper No. 138, October 2010.

Fallah, Katherine, "Corporate Actors: the Legal Status of Mercenaries in Armed Conflict", International Review of the Red Cross, Vol. 88, No. 863, September 2006.

Vandenberg, Martina E. and Kathleen Peratis, "Trafficking of Women and Girls to Bosnia and Herzegovina for Forced Prostitution", Human Rights Watch, Vol. 14, No. 19, 2002.

Belo, Nelson, 'Saida Mak Akontese Ba Kompaña Siguransa Privadu iha Futuru?', Fundasaun Mahein, Vol. 27, 2011.

\section{Websites}

East Timor Law and Justice Bulletin, "Prime Minister Gusmao Lashes out at AntiCorruption Commission", http://pdf.usaid. gov/pdf_docs/PNADQ697.pdf, accessed on 30 June 2014.

Geneva Centre for the Democratic Control of Armed Forces, "Private Military Companies", http://www.dcaf.ch/content/ download/34953/525123/file/bg_p rivatemilitary-companies.pdf, accessed on 30 June 2014.

Boemcken, Marc von, "Brief 45, Commercial Security and Development: Findings from Timor-Leste, Liberia and Peru", http://www. bicc.de/uploads/tx_bicctools/brief45.pdf, accessed on 30 June 2014.

Ghouri, Nadene, "How to Make a Killing in Kabul: Western Security and a Crisis in Afghanistan", http://www.dailymail.co.uk/home/moslive/ article-1360216.html, accessed on 30 June 2014.

Vaknin, Sam, "Private Armies", http://www. sandline.com/hotlinks/ private_armies.html, accessed on 30 June 2014.

Parker, Sarah, "Handle with Care: Private Security Companies in Timor-Leste", http://www. timor-leste-violence.org/pdfs/Timor-LesteViolence-Private-Security-Companies.pdf, accessed on 30 June 2014.

Security Sector Reform Resource Centre, "Country Profile: Timor-Leste", http:// $w w w$.ssrresourcecentre.org/wp-content/ uploads/2010/04/Country-Profile-TimorLeste-April-7.pdf, accessed on 30 June 2014. The Guardian, "US Embassy Cables: Afghan Government Asks US to Quash 'Dancing Boys' Scandal", http://www.guardian. co.uk/world/us-embassy-cablesdocuments $/ 213720$, accessed on 30 June 2014.

UniversityCentreforInternationalHumanitarianLaw Geneva, "Expert Meeting on Private Military Contractors: Status and State Responsibility for Their Actions", http://www.genevaacademy.ch/docs/expertmeetings/2005/ 2rapport_compagnies_privees.pdf, accessed on 30 August 2005.

US Agency for International Development, "Corruption Assessment: Timor-Leste", http://pdf.usaid.gov/pdf_docs/PNADQ697. $p d f$, accessed on 30 June 2014.

\section{Regulations}

Act No. 56 of 2001 on Private Security Industry Regulatory.

Agreement Between the United States of America and the Republic of Iraq On the Withdrawal of United States Forces from Iraq and the Organization of Their Activities during Their Temporary Presence in Iraq, 17 November 2008.

Coalition Provisional Authority Order No. 17 (Revised). 
Código de Registo Comercial, aprovado pelo Decreto-Lei $n^{\circ} 7$ of 2006 de 1 de Março de 2006.

Congressional Budget Office, Contractor's Support of U.S. Operations in Iraq, 2008.

Decreto-Lei n ${ }^{\circ} 24$ of 2011 de 8 de Junho 2011on Licenciamento das Actividades Comercias.

Despacho No. 03/GABSES/VII/2010 de 6 de Agosto 2010.

International Code of Conduct for Private Security Services Providers, opened for signature 9 November 2012.

International Code of Conduct for Private Security Services Providers.

Montreux Document on Pertinent International Legal Obligations and Good Practices for States related to Operations of Private
Military and Security Companies during Armed Conflict.

Montreux Document on Pertinent International Legal Obligations and Good Practices for States Related to Operations of Private Military and Security Companies During Armed Conflict.

National Parliament Law No. 4 of 2010 on Law of Internal Security.

United Nations, Report of the Working Group on the Use of Mercenaries, Mission to Ecuador, UN Document A/HRC/4/42/Add.2, 9 [21].

\section{E. Court Verdict}

Verdict Arias, et al., v DynCorp, et al., Case No. 1:01-cv-01908-RWR 2. 